\title{
DETECTION OF CRACKS IN COMPOSITE MATERIALS USING HYBRID NON-DESTRUCTIVE TESTING METHOD BASED ON VIBRO-THERMOGRAPHY AND TIME-FREQUENCY ANALYSIS OF ULTRASONIC EXCITATION SIGNAL
}

\section{HYBRYDOWA METODA BADAŃ NIENISZCZĄCYCH DO WYKRYWANIA USZKODZEŃ W MATERIAŁACH KOMPOZYTOWYCH BAZUJĄCA NA WIBRO-TERMOGRAFII I ANALIZIE CZĘTOTLIWOŚCIOWO-CZASOWEJ SYGNALU POBUDZAJĄCEGO}

\author{
Wojciech Prokopowicz \\ Politechnika Poznańska \\ e-mail:wojtek379@wp.pl
}

\begin{abstract}
The theme of the publication is to determine the possibility of diagnosing damage in composite materials using vibrio-thermography and frequency analysis and timefrequency of excitation signal. In order to verify the proposed method experiments were performed on a sample of the composite made in the technology of pressing prepregs. Analysis of the recorded signals and the thermograms were performed in MatLab environment. Hybrid non-destructive testing method based on thermogram and appropriate signal processing algorithm clearly showed damage in the sample composite material.
\end{abstract}

Keywords: vibro-thermography, ultrasound, composite, thermogram, time-frequency analysis

Streszczenie: Tematem publikacji jest określenie możliwości diagnozowania uszkodzeń materiatów kompozytowych przy użyciu wibrotermografii oraz analizy częstotliwościowej i czasowo częstotliwościowej sygnatu pobudzajacego. W celu weryfikacji zaproponowanej metody przeprowadzono eksperymenty na próbce kompozytu wykonanej w technologii prasowania prepregów. Analizę rejestrowanych sygnałów oraz termogramów wykonano w środowisku MatLab. Zastosowana hybrydowa metoda badań nieniszczacych dzięki odpowiedniemu algorytmowi przetwarzania sygnatów pokazała, że da się jednoznacznie określić uszkodzenia w analizowanej próbce materiału kompozytowego.

Stowa kluczowe: vibrotermografia, ultradźwięki, kompozyt, termogram, analiza czasowo-czestotliwościowa 
Detection of cracks in composite materials using hybrid non-destructive testing... Hybrydowa metoda badań nieniszczacych do wykrywania ...

\section{Introduction}

In our times, a process of implementing composites on a large scale to the aircrafts' construction, in both, the civil and military aviation, was initiated. Such approach is reasonable when the improvement of aircraft's performance is considered. Composites are materials of non-homogeneous structure, made up of two or more constituents (phases) having different physical properties. Most often, one of the constituents is a resin guaranteeing that the composite is cohesive, hard, elastic and resistant to compression, and the second one, so-called structure constituent, brings most of other mechanical properties. Due to the application of such materials in military aviation, the aircraft of the reduced dimensions is able to carry larger operational payload and armour, and its flying range and manoeuvre ability have increased. In civil aviation, using composites allowed to carry more passengers and cargo (an example of an aircraft whose structure in 50\% is made of composites is the cutting-edge passenger aircraft Boeing 787 Dreamliner). Composite materials are widely used in a new branch of aviation, i.e. in unpiloted aerial vehicles (drones). Northrom Grumman, the manufacturer of UAV (Unmanned Aerial Vehicle) RQ-4 Global Hawk, has applied in wings structure carbon composites, among others, for ribs, leading edges and the outer coating of wings.

Taking the flight safety into consideration, usage of composites requires conducting a thorough analysis of their strength during operational use. Components of aircraft structure made from composites are subject to damage; and when the operational use of airframe structure is considered, it is reasonable to localize cracks in those materials at a very early stage using methods of nondestructive testing being developed just for this purpose. Damage to composite materials should be divided into some types: damage formed during the production process, mechanical damage and damage made as a result of interaction with environmental factors (such as atmospheric discharge, icing, excessive exposure to sunlight). Composites exposed to the mechanical damage often return to their initial state and during visual inspection it is impossible to localize such damage since it often concentrates inside the material under the paint coating of, for example, wing structure (fig. 1). For duraluminum structures such damage is visible at once.

The main factor which can affect the localization of damage to the aircraft structures made of composites is lack of clear methods of non-destructive testing for such structures. Work on standards and principles of using the already-existing methods of non-destructive testing, such as active thermography, vibrothermography, vibroacoustic diagnosis and other methods for testing structures of that type, is still proceeding across the world. 


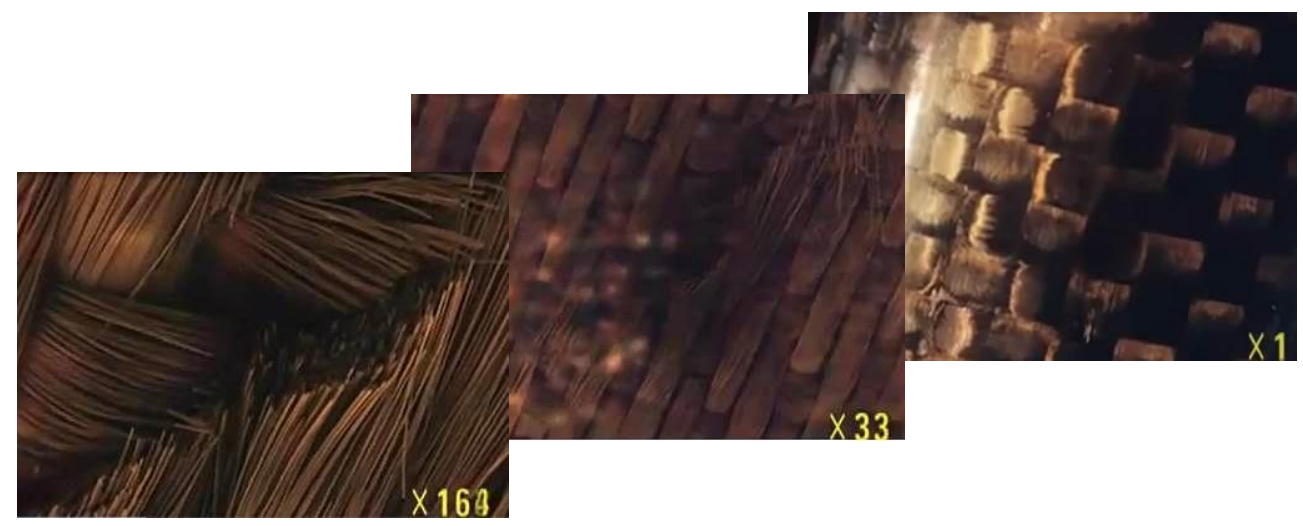

Fig. 1 Internal damage. Example of internal damages in the composite material based on carbon fibres oriented at the angle of $0-90^{\circ}$, made using pressing prepregs technology (instructional materials from the International Flight Safety Officer Course Kitrland AFB USAF).

The proposed hybrid method creates the possibility for diagnosing those nonmetallic materials and opens an interesting path for research phenomena in composites. Based on it, it will be possible to develop devices which will use appropriately controlled sets of ultrasonic transmitting heads creating synthetic apertures, what in connection with the change of amplitude, phase and power of the emitted working signal will enable more thorough analysis of damage to the composite materials, despite the technology of manufacturing the composite and its dimensions.

\section{Description of testing method}

A sample of composite material of dimensions of $175 \times 150 \times 0.45 \mathrm{~mm}$ based on fibres oriented at the angle of $0-90^{\circ}$, of smooth surface of a fabric structure, made using pressing prepregs technology, was used for tests. To conduct them, a test stand based on NE555 generator system and a piezoelectric vibration sensor connecting with the PC via the Amtel AT mega 328 system was designed and built. Thermal pictures were made using FLIR i5 thermal imaging camera. Test was divided into two stages. The first stage is the sample temperature measurement using the thermal imaging camera in the presence of ultrasonic excitations. Excitation vibrations are generated in piezoelectric head by sinusoid signal of the frequency of $40 \mathrm{kHz}$ and the power of $30 \mathrm{~W}$. After starting the system, composites were exposed to ultrasonic vibrations for 12 minutes. During the measurement, the sample is gradually heated at the place of damage. In tests, ultrasonic excitation in a form of transverse wave of frequency of $40 \mathrm{kHz}$ and power of $30 \mathrm{~W}$ or $50 \mathrm{~W}$ was used. Results of tests conducted on a material are presented as thermograms (fig. 2 ); visible place of damage in a form of a bright field on the thermogram of the damaged element shows the place of high temperature concentration (fig. 2b). 
Detection of cracks in composite materials using hybrid non-destructive testing... Hybrydowa metoda badań nieniszczacych do wykrywania ...

To verify the obtained results, the comparative analysis was done by the MatLab program. Thermogram being the difference of temperatures between the good sample (fig. 2a) and the damaged one shows clearly the place of damage in a form of a dark spot (fig. 2c).

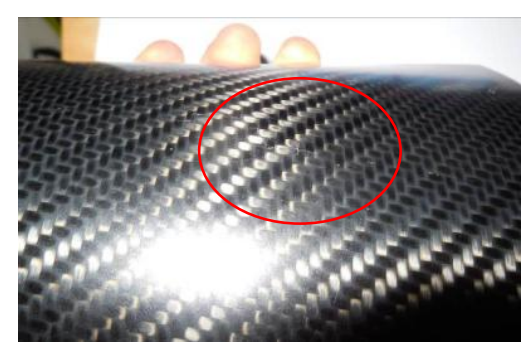

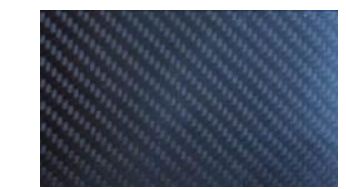

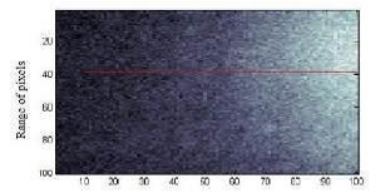

Ramge of pixels

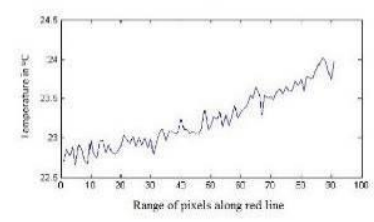

a)
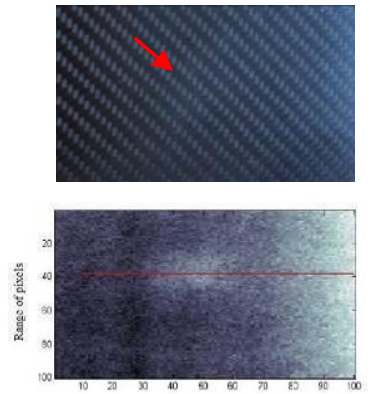

Ramge of pixels

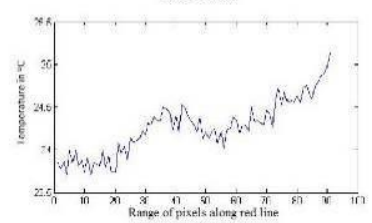

b)
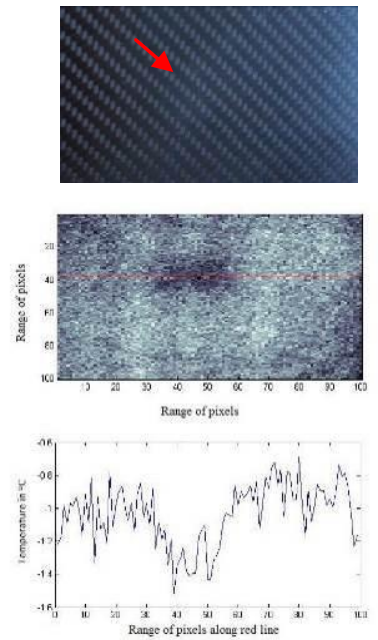

c)

Fig.2 Composite plate of dimensions of $175 \times 150 \times 0.45 \mathrm{~mm}$ made of carbon fibres oriented at the angle of $0-90^{\circ}$ in prepregs pressing technology, of smooth surface of a fabric structure. The first two images $a$ ), $b$ ) are pictures from a thermal imaging camera. The third image c) is the image created in MatLab program - it is the difference of the first two thermal images with visible dark spots at areas of damage. Below the thermogram charts there are graphs of changes of temperature on the surface of the sample measured along the line.

The proposed method of non-destructive testing combines two different methods of testing. First of them was just discussed. The next part discusses the measurements of vibrations made using the ultrasonic head at the place of damage to the sample, previously localized using thermal imaging camera; similar measurements were made in the same region of the good sample. Next, the measurement of excitation signal was repeated to enlarge the already-existing damage. 
Vibration signal at the place of damage was registered for six minutes. Changes in voltage of the piezoelectric element of the head (fig. 3a) are sent to the computer via properly programmed measuring module. Data saved in a file were analysed in the MatLab environment by calculating the Fourier transform for the signal of changes in voltage of the transducer as a time function for the good and damaged sample (fig. 3b, 3d).

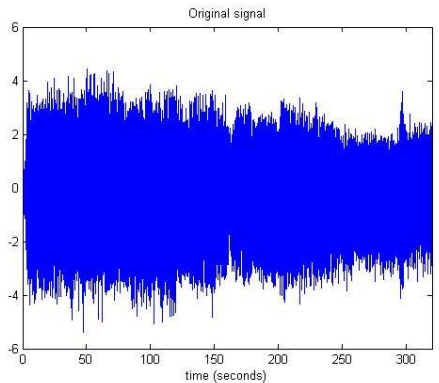

a)
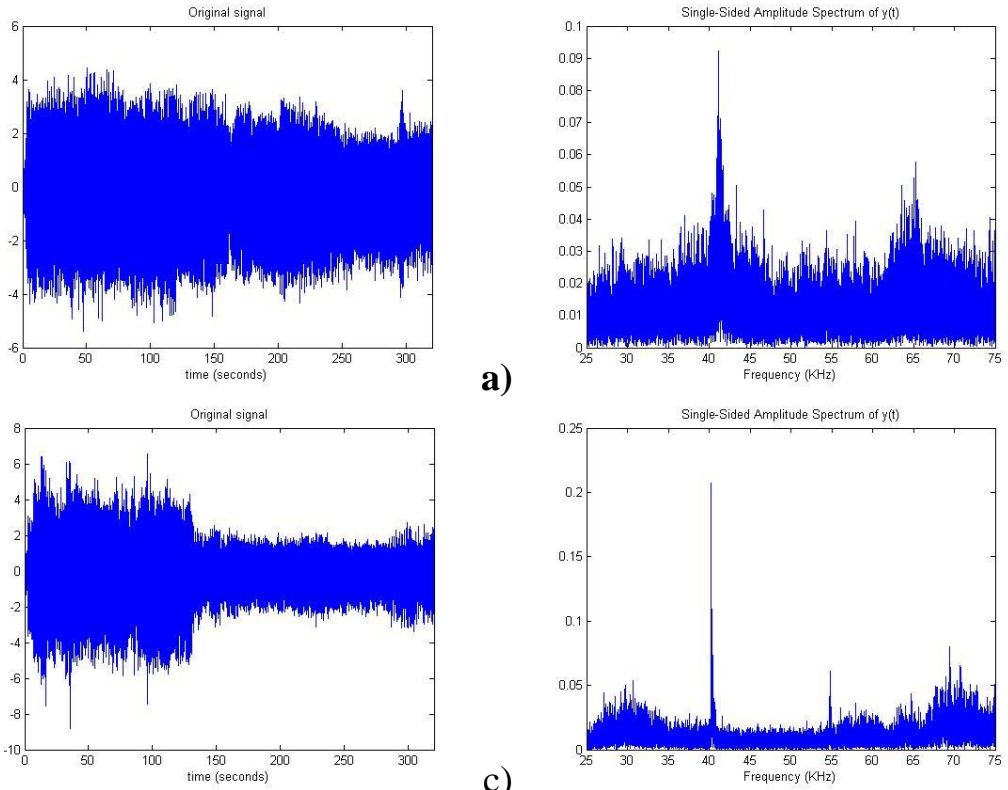

b)

c)

d)

Fig.3 Spectral representation of the ultrasonic vibrations signal at the place of damage to the composite plate of dimensions $175 \times 150 \times 0.45 \mathrm{~mm}$ made of carbon fibres oriented at the angle of $0-90^{\circ}$ in prepregs pressing technology, of smooth surface of a fabric structure.

a) signal in time domain - the good sample, b) signal spectrum - the good sample c) signal in time domain - the damaged sample, d) signal spectrum - the damaged sample.

Unfortunately, representations of signal spectrum are illegible and have many disturbances originated, among others, from white noise and resonant frequency occurring as a result of impact of the excitation signal on components of the measuring path. Figure $3 \mathrm{c}$ presents the representation of the signal in time domain after filtrating it using the band-pass filter with the band pass between $25 \mathrm{kHz}$ and $80 \mathrm{kHz}$. After filtrating, vibration signals for the good and the damaged sample were subject to the Fourier analysis. Spectrum becomes more legible and peaks, which may originate in signal frequencies formed at the place of damage, become noticeable. To separate signal frequencies originating in damage to the sample, the matrix of signal after filtrating was averaged in frequency domain using the Bartlett method; such obtained imaging is presented in fig. 4. 
Detection of cracks in composite materials using hybrid non-destructive testing... Hybrydowa metoda badań nieniszczacych do wykrywania ...

a)
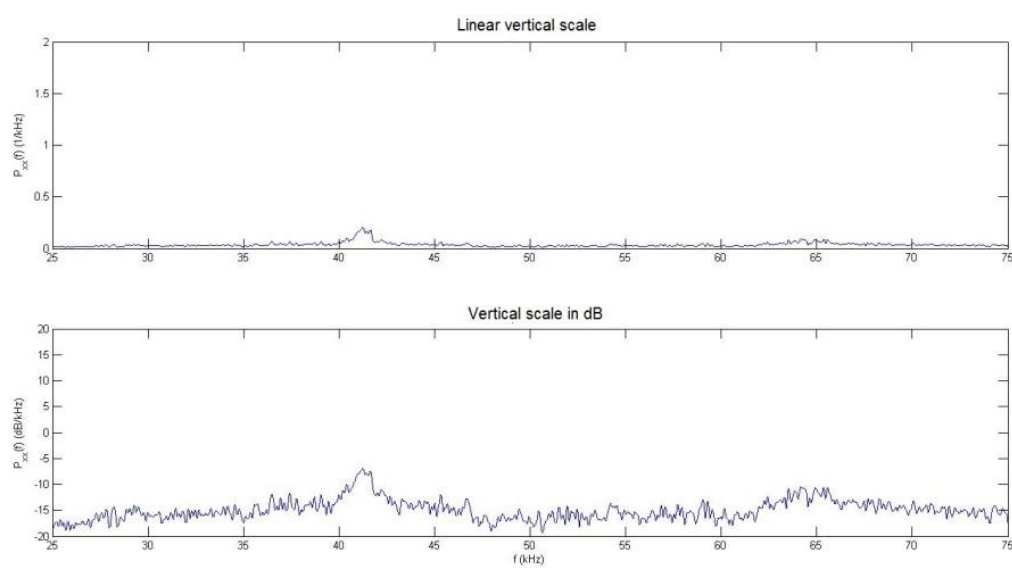

b)
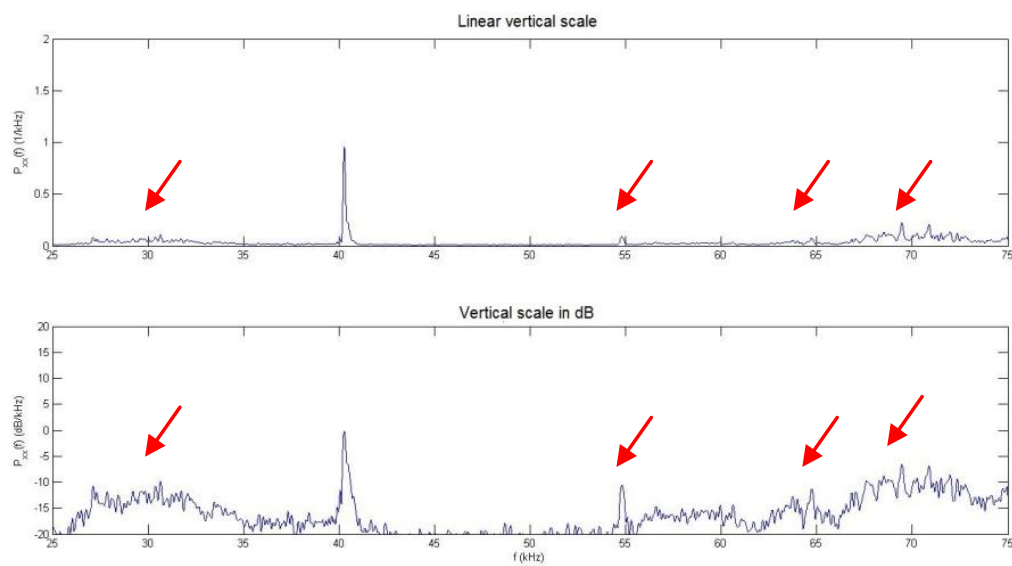

Fig. 4 Spectrum of ultrasonic vibration signal at the place of damage to the composite plate of dimensions $175 \times 150 \times 0.45 \mathrm{~mm}$, made of carbon fibres oriented at the angle of 0-90 in prepregs pressing technology, of smooth surface of a fabric structure averaged using the Bartlett method.

a) signal spectrum - the good sample, b) signal spectrum - the damaged sample.

In the spectrum of the vibration signal originating in the damaged sample, additional frequencies are noticeable, which do not occur in the signal spectrum of the good sample. These are peaks of frequency of $32 \mathrm{kHz}, 55 \mathrm{kHz}, 64 \mathrm{kHz}$, and 68 $\mathrm{kHz}$ (they are marked in fig. $4 \mathrm{~b}$ with red arrows). Analysing the amplitude of signal vibrations, it can be noticed that it differ from the amplitude of signal vibrations in time, what results from the occurrence of disturbances. In both spectra, the frequency of about $40 \mathrm{kHz}$ is clearly visible; it represents the excitation signal. 
To verify the correctness of the analysis in the frequency domain, the damage to the sample was enlarged. The obtained results show that the peaks proving the damage are on the same frequencies and their amplitude increases, with exception of the peak of excitation signal of $40 \mathrm{kHz}$, which is slightly reduced, but still clearly visible (fig. 5). Additionally, the peak of the frequency of $32 \mathrm{kHz}$ was shifted to the frequency of $28 \mathrm{kHz}$ with the disappearance of the peak of $64 \mathrm{kHz}$.

a)
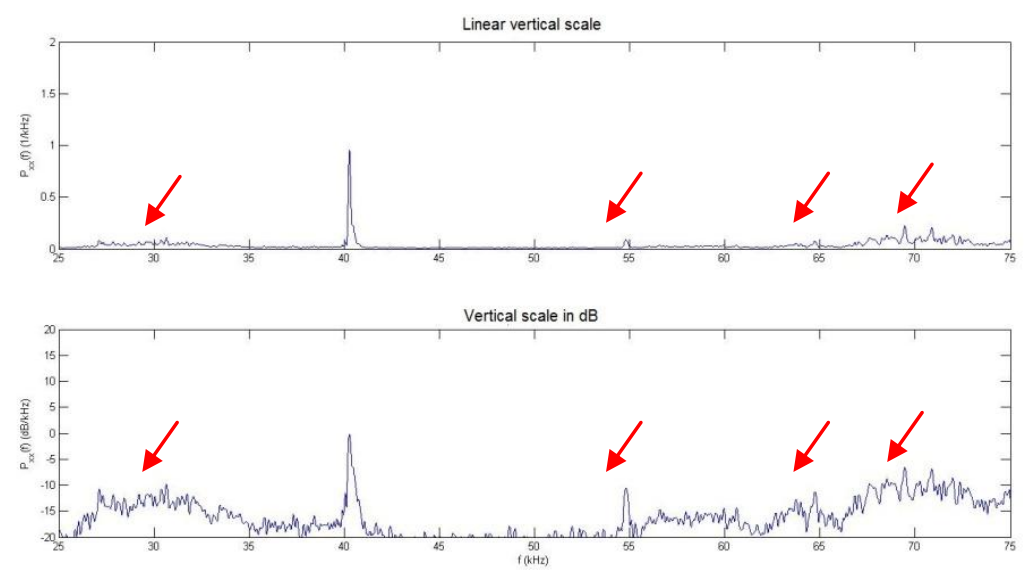

b)
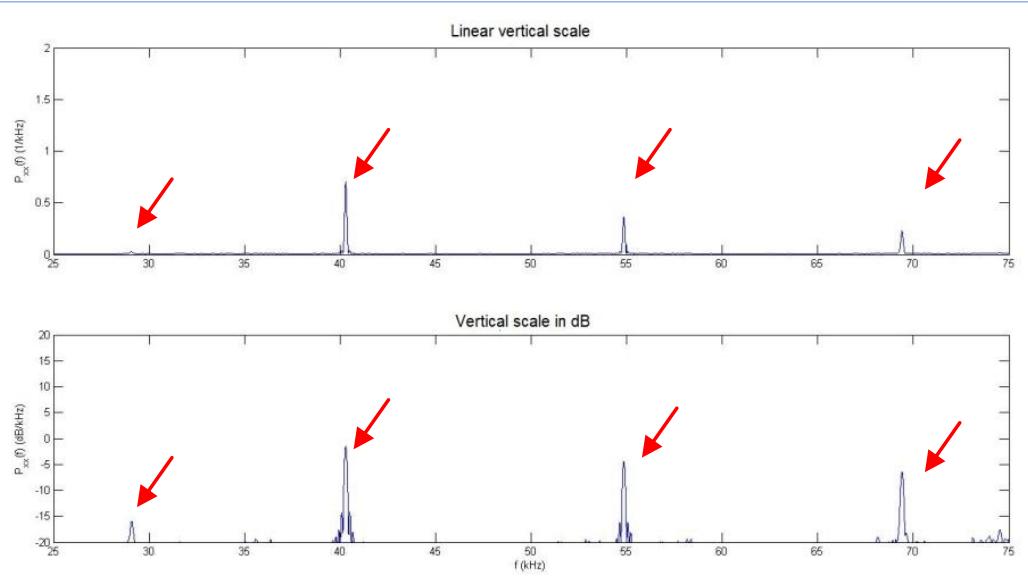

Fig. 5 Spectrum of ultrasonic vibration signal at the place of damage to the composite plate made in prepregs pressing technology, after enlarging the damage, averaged using the Bartlett method. Visible increase in peaks amplitude on the frequency of $55 \mathrm{kHz}, 68 \mathrm{kHz}$ and separation of the peak of frequency of $28 \mathrm{kHz}$ from the spectrum, not $32 \mathrm{kHz}$, as previously.

a) sample damaged originally, $b$ ) sample with the enlarged damage. 
Detection of cracks in composite materials using hybrid non-destructive testing... Hybrydowa metoda badań nieniszczacych do wykrywania ...

For all obtained spectrum representations, a rectangular window was used since it is the best one for analysing long-lasting signals for which the length of the measuring window is exactly equal the integer number of cycles.

However, it turns out that the assumed analysis model did not bring unambiguous results with respect to the phenomenon of shifting the peak from the frequency of $32 \mathrm{kHz}$ to the frequency of $28 \mathrm{kHz}$, that is, one of our spectral estimators. It means that the tested signal may change its frequency structure over time.
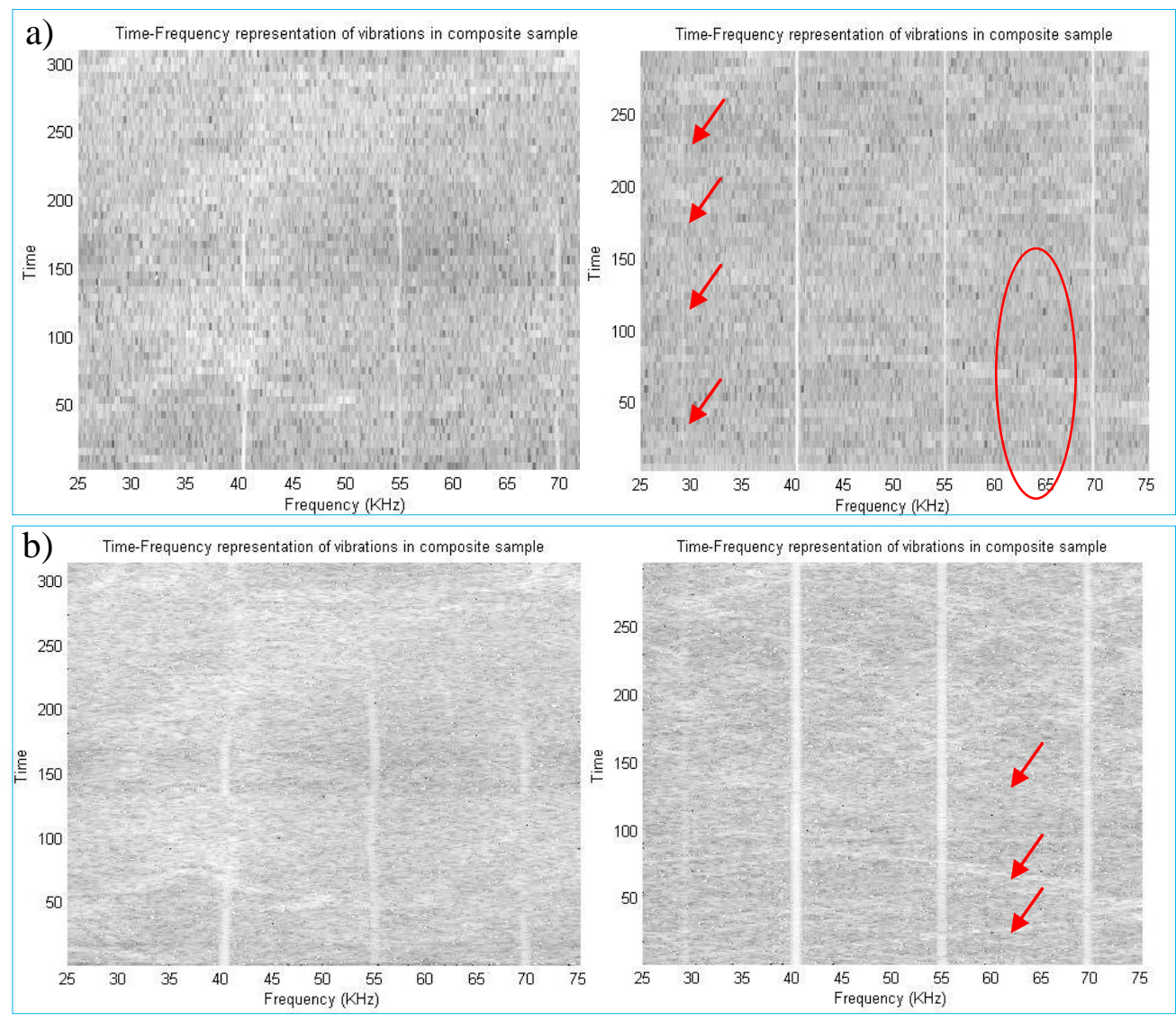

Fig. 6. Influence of the cut-off window length $l$ on the form of spectrogram obtained using the STFT method:

a) the damaged sample and the enlarged damaged sample $l=1024$, lack of frequency of $64 \mathrm{kHz}$ (region marked with $w$ circle, barely visible frequencies of $55 \mathrm{kHz}$ and $68 \mathrm{kHz}$ ),

b) the damaged sample and the enlarged damaged sample $l=256$, frequency of $64 \mathrm{kHz}$, which may prove the damage, is barely visible and is fading, clearly visible frequencies related to the defect of the material for $28 \mathrm{kHz}, 55 \mathrm{kHz}$ and $68 \mathrm{kHz}$. Horizontal axis represents the frequency, vertical axis represents time. 
To prove this thesis, third stage of the presented hybrid method was introduced, that is, application of time-frequency analysis of the excitation signal. In order to do that, the signal was analysed in the MatLab environment by calculating STFT spectrograms which, being a three-dimensional function of the spectrum amplitude as time and frequency functions, show what part of signal energy is included in a specific frequency band in the exactly defined period of time. Right choice of shape and length of the window cutting-off the signal is decisive for the success of the analysis. Usage of the long Kaiser window $l=1024$, fig. 5a) (with the assuming sampling frequency of $150 \mathrm{kHz}$ it means the length of approx. 6 milliseconds) gives a good frequency resolution (horizontal axis), while the time resolution is impossible to accept for the frequency under testing, that is $28 \mathrm{kHz}, 64 \mathrm{kHz}$ since we are not able to determine unambiguously when the occurrence of those components will end, when compared to other components. This type of analysis is called the narrowband analysis [5]. Narrowing the window three times, to approx. 2 milliseconds ( $=256$, fig. 5b), improves definitely the location of separate components in time, however, the band broadening along the frequency axis becomes noticeable (broadband analysis).

\section{Theoretical basis}

Temperature of the tested material sample increases significantly under the influence of ultrasounds, what is caused by friction of particles of the composite material internal structure. It is possible that local zones of material plastifying are formed, for instance in the vicinity of cracks, what results in the increase of temperature in these places. It is also possible that heat is generated at places of structural defects, resulting from friction of the opposite walls of crack or from delamination. Based on paper [1] we may state that every material displays some deviation from an ideally resilient behaviour, even for small deformations. In the case of periodical excitation those deviations are manifested by permanent loss of energy in material. Such energy losses may result from converting mechanical energy into heat, extending micro-cracks and other discontinuities of the structure, plastic deformation of crystal structure, etc. Energy losses in material are determined, for example, by dumping, energy dissipation, non-ideal resilience or internal friction. Phenomena of such type occurred on all stages of testing. They influenced on heat generation in the sample material and during the measurement of the excitation signal they disturbed it at the crack of composite. Wherever the structural damage occurs, the increased mechanical compliance occurs; hence more energy is lost as heat. Analysis of images obtained during thermal imaging measurement allows identifying defects to the structure. Heat generated in places of damage propagates into the surface of the object, where it may be measured using the IR camera. Such obtained thermograms enable to identify structural defects. Among basic physical quantities describing heat radiation is emissivity of temperature, characterizing the solid body radiation properties. The emissivity value depends on parameters characteristic of a given material [1], that is, temperature, chemical composition, physical condition of the surface (emissivity is defined during measurement as a parameter in IR camera menu). The main purpose of ultrasonic excitation is to induce thermal phenomena in the material structure of the components under test by an external system of ultrasonic excitations. Dependence between deformation, stress and temperature change is described by the following formula [1]: 
Detection of cracks in composite materials using hybrid non-destructive testing... Hybrydowa metoda badań nieniszczacych do wykrywania ...

$$
\Delta \varepsilon=\frac{(1-2 v) \Delta \sigma}{\mathrm{E}}+3 \alpha \Delta T
$$

Change of main deformations $\Delta \varepsilon$ depends on: change of main stresses $\Delta \sigma$, the Poisson's coefficient $v$, change of temperature $\Delta \mathrm{T}$, thermal expansion coefficient $\alpha$, and Young's modulus E.

Assuming that changes of stresses occur very quickly (it is assumed that the frequency of changes is greater than $3 \mathrm{~Hz}$; it can be assumed that thermodynamic changes are adiabatic and that there is no need to take the heat exchange with surroundings into consideration), we may state that the change of deformation $\Delta \varepsilon$ causes the change of temperature $\Delta \mathrm{T}[1]$ :

$$
\Delta T=\frac{-3 T \alpha K \Delta \varepsilon}{\rho \mathrm{C}_{v}}
$$

Change of temperature $\Delta \mathrm{T}$ depends on the coefficient of compressibility $\mathrm{K}[\mathrm{Pa}]$, specific heat $\mathrm{C} v[\mathrm{~J} / \mathrm{kg} \mathrm{K}]$ at constant volume, $\rho-$ density $[\mathrm{kg} / \mathrm{m} 3]$, and temperature of the body under testing $\mathrm{T}[\mathrm{K}]$.

As a result, an approximated dependence describing the phenomenon of thermoelasticity is obtained in the following form:

$$
\Delta T=\frac{\alpha}{\rho \mathrm{C}_{p}} T \Delta \sigma=\mathrm{K}_{m} T \Delta \sigma
$$

Change of temperature $\Delta \mathrm{T}$ depends on specific heat at constant pressure $\mathrm{Cp}$ and thermo-elastic coefficient $\mathrm{Km}$.

Change of temperature is proportional to change of stress of the tested component. Absolute temperature of the tested object should be eliminated in this method. It is done by filtrating the constant component at the stage of processing the registered images or, optionally, using special techniques of synchronization images sampling with thermal excitation of the tested object [2]. This method enables to determine changes in stress field caused by damage to the structure [3].

To verify damage to samples of composite materials, detected based on thermograms, an examination of ultrasonic excitation signal at the place of the detected damage was performed. As a result of spectral analysis of signals and time-frequency analysis of excitation signal, peaks of frequency of $28 \mathrm{kHz}, 55$ $\mathrm{kHz}$, and $68 \mathrm{kHz}$ in the presence of excitation signal frequency of $40 \mathrm{kHz}$ become visible in the spectrum. Occurrence of such frequencies is related to the change in the intensity of ultrasonic wave propagating in solid mediums, which, in the discussed case, has changed.

It resulted from two factors:

- absorption caused by a loss of part of the wave energy due to heat generated as a result of particles internal friction at the place of damage (peaks of frequency of $28 \mathrm{kHz}$ );

- scattering (non-directional reflection) of a wave from boundaries occurring in polycrystalline mediums of inhomogeneous structure or even having internal defects of macroscopic dimensions (peaks of frequency of $55 \mathrm{kHz}, 64 \mathrm{kHz}, 68$ $\mathrm{kHz}$ ) (in the considered case, the frequency of $64 \mathrm{kHz}$ is fading gradually). 
Velocity of ultrasonic signal in a given medium depends on various factors, such as stress and density for solids.

The amount of energy loss is defined by energy damping coefficient $\gamma$. It helps to determine the intensity of the wave I as a function of its path 1 .

$$
I=I_{0}-e^{-\gamma}
$$

The intensity of the wave $\mathrm{I}$ is proportional to the intensity of the initial wave $\mathrm{I}_{0}$ and the natural logarithm e.

The value of the damping coefficient grows with the increase in waves' frequency. Similar effect is obtained with the increase in the material grain size. Relationships between the intensity of the wave and the path as well as between the damping coefficient and the frequency are presented in figures $7 \mathrm{a}$ ) and $7 \mathrm{~b}$ ).

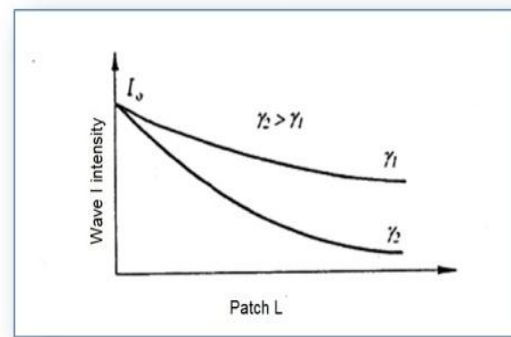

a)

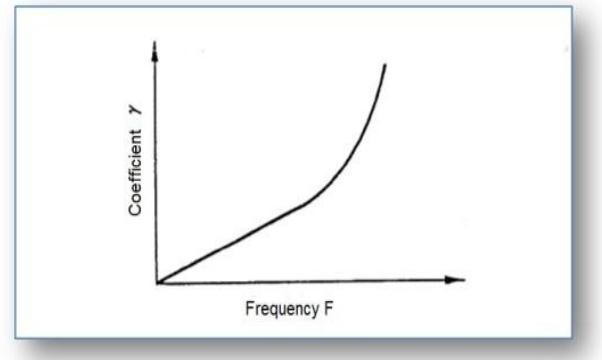

b)

Fig. 7 Relation between a) wave intensity and the path and b) damping coefficient and the frequency

Transverse waves, so-called shear waves, causing shearing stresses, were used during test. Particles of medium oscillate in a plane perpendicular to the direction of wave's propagation. Propagation of such waves is not accompanied by changes in medium density. Those waves propagate only in solid mediums.

At the second stage of determining the excitation signal spectrum, windowing was used based on rectangular window characterized by high level of side lobes (the amplitude of the highest side lobe is $-13.3 \mathrm{~dB}$ ) and by low characteristic slope $(-20 \mathrm{~dB} /$ decade). However, its undoubted merit is the highest resolution of those possible to be achieved with the given signal length. Spectral leakage results from the signal discontinuity at its endings being produced by windowing.

It is possible to reduce this discontinuity by applying windows of different shapes, as, for example, the Kaiser window (window used in the third stage of testing for time-frequency analysis).

The lower is the degree of time characteristic squareness of the cutting-off window, the greater signal power is cumulated in the main lobe, and consequently, the lower 
Detection of cracks in composite materials using hybrid non-destructive testing... Hybrydowa metoda badań nieniszczacych do wykrywania ...

is the signal power dissipation in side lobes. Unfortunately, this effect is obtained at the expense of the main lobe broadening, what causes the loss of the analysis resolution.

Classical algebraic window of a rectangular shape (for example, see fig. 8), used at the second stage of testing, is described in the discrete time domain by a general equation:

$$
w_{\alpha}(n)=1-\left|\left(n-\frac{N-1}{2}\right) /\left(\frac{N+1}{2}\right)\right|^{\alpha}
$$

where $\alpha=1,2,3, \ldots \infty$

It is characterized by the loss of the resolution expressed by the coefficient $\eta_{\alpha}$ expressed by the formula:

$$
\eta_{\alpha}=1+\frac{1}{2 \alpha+1}
$$

for the rectangular window $\alpha=\infty$.

$$
w_{R}(n)=\left\{\begin{array}{l}
1, n \in[0, N-1] \\
0, n \notin[0, N-1]
\end{array}\right.
$$
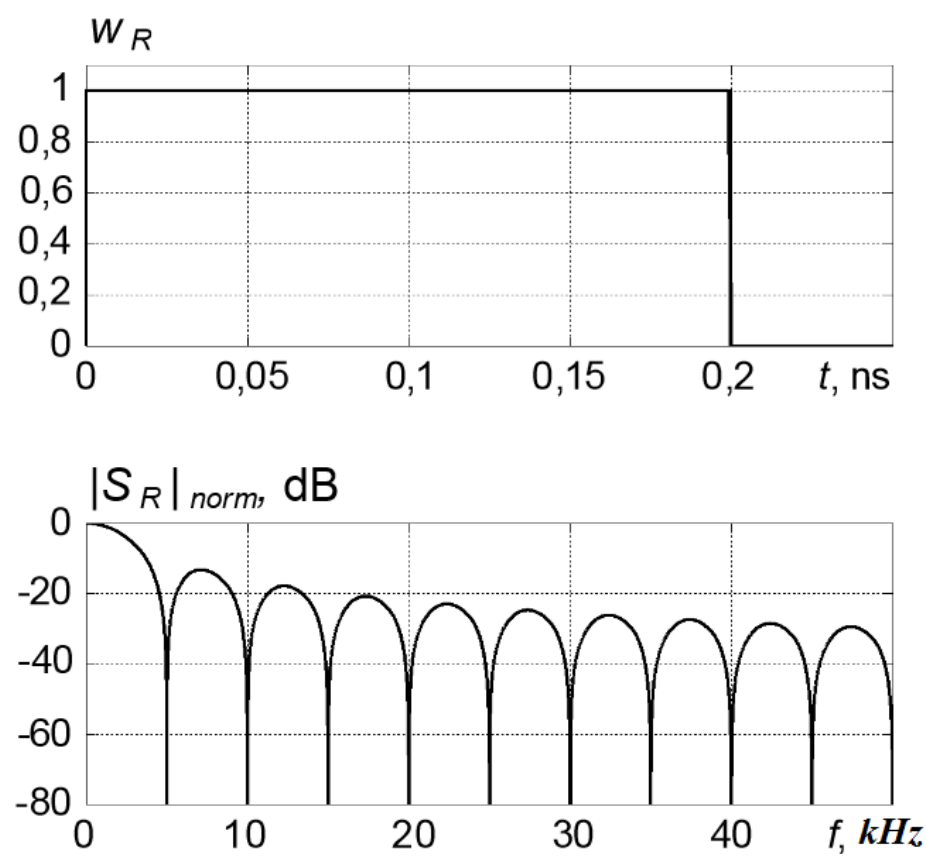

Fig. 8 Rectangular window of the length $t=0,2 \mathrm{~ns}$ a) time characteristics b) standardized spectrum 
Third stage of testing was related to the analysis in the joint time-frequency domain. To calculate the energy concentration and its presentation in a form of peaks located in the particular moment of time, the STFT spectrogram (method of calculating transform of the signal described as the Short-Time Fourier Transform) was applied. This method consists in dividing the whole tested signal using specially chosen window (for our tests we used windowing by Kaiser window; fig. 9) into shorter, overlapping segments, where the signal is still stationary. Next, the local Fourier transforms should be calculated in those windows, and after raising them to their square, such obtained spectra should be "put together" according to time flow.

Short-Time Fourier Transform for the signal $s(\tau)$ is described by the dependency:

$$
S_{d}(\omega, t)=\int_{-\infty}^{+\infty} s(\tau) w(\tau-t) \exp (-j \omega \tau) d \tau
$$

where $S_{d}(\varpi, t)$ - is the complex spectral function of STFT transformation, $₫(\tau)$ - is the time window function (in our case - the Kaiser window).

For numerical calculations made for the sampling process, the STDT transformation is calculated based on the formula:

$$
S_{d}(\omega, m)=\sum_{n=0}^{N-1} s(n) w(n-m) \exp (-j \omega n)
$$

where $\mathrm{n}$ and $\mathrm{m}$ describe the discrete time, and $\mathrm{N}$ determines the integer number of samples in the considered time interval. The formula describing the Kaiser window is as follows:

$$
w(n-m)=\frac{I_{0}\left(\pi \alpha \sqrt{1-\left(\frac{2 \pi}{N-1}-1\right)^{2}}\right)}{I_{0}(\pi \alpha)}
$$
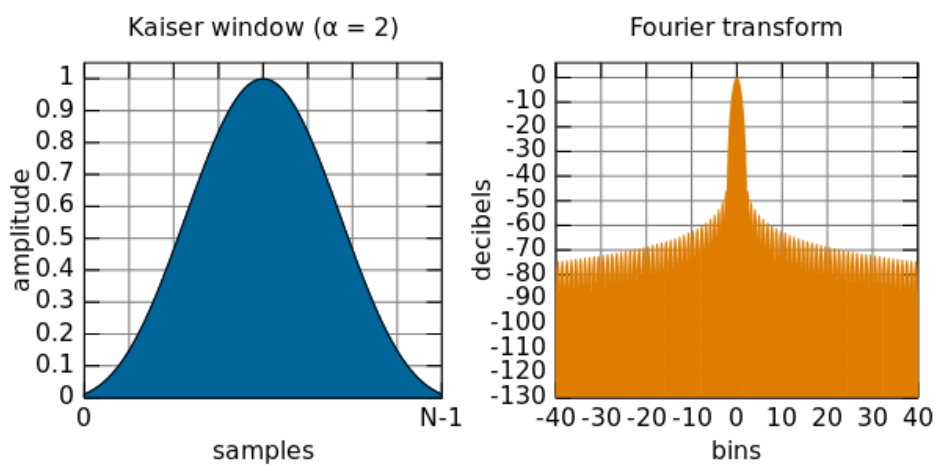

Fig. 9 Kaiser window for $\alpha=2$ 
Detection of cracks in composite materials using hybrid non-destructive testing... Hybrydowa metoda badań nieniszczacych do wykrywania ...

Characteristic for testing non-metals is applying, to a greater extent than for metals, measurements of damping and velocity of ultrasonic waves. Those quantities often characterize not only the microscopic structure, but also essential performance properties, such as compression strength, tensile strength, porosity. It enables monitoring not only finished products, but also manufacturing processes. In the tested samples all the described phenomena occurred, what was manifested by resonant frequencies as well as by excitation wave absorption. Phenomena occurring in the tested material require further research. The quality of measurement was influenced by noise of the measuring path, which may be eliminated by filtration of both signals coming from the good and the damaged sample. At further research stages one may try to introduce a few sources of the ultrasonic signal and to analyse signals received in various places of the sample using the correlation function [4].

\section{Conclusions}

Testing method applied in this paper shows that it is possible to determine areas of damage to the composite components using thermal imaging camera in the presence of ultrasonic excitations and to verify their occurrence using the Fourier analysis and time-frequency analysis of the excitation signal registered by the vibration sensor at the place of damage. Comparing both cases of spectral analysis for samples less and more damaged, we may notice peaks of frequency of $28 \mathrm{kHz}$, $55 \mathrm{kHz}$, and $68 \mathrm{kHz}$, which prove the damage to the composite structure. It is noteworthy that the peak of frequency $64 \mathrm{kHz}$, not present in the good sample, is fading. Application of time-frequency analyses such as the Wigner-Ville analysis, the Gabor analysis or the adaptive method will allow to create spectrogram enabling to determine whether this disturbance is related to the damage, but this problem is a material for another publication. All the obtained spectrograms show that for different types of windows (here, the Kaiser window was used for analysis) as well as choosing different length of the window, it is possible to change the resolution of the analysis, in both, the time and the frequency domains. It enables to determine whether anomalies have occurred during the whole registration time or they were only disturbances in the measuring path. The obtained measurement results were compared with results for other composite material made using the pultrusion technology (not presented herein), for which similar results were obtained with regard to both, temperature concentration at the place of damage visible in thermogram and the frequencies in the spectrum proving the damage. At all stages of testing proper signal filtration was used, what enables to separate disturbances in the measuring path from the white noise, and averaging with the Bartlett method allowed isolating unambiguously frequency peaks of the registered 
signal originating in damage to the internal structure of composites. The entire method enables to create two maps of damage: the first one based on the thermogram, and the second one based on analysis of signal received from the selected area of the sample. Comparison of those two maps allowed determining unambiguously damage to the tested sample of composite material.

\section{References}

[1] Maldague X.: Nondestructive testing of materials using infrared thermography, Springer, London, 2007.

[2] Dillenz, G.Buse, D. Wu: Ultrasound lockin thermography: feasibililties and limitations, Diagnostic imaging technologies and industrial applications. SPIE Vol. 3827 (1999) S. 10 -15.

[3] Busse G.: Techniques of infrared thermography: Part 4. Lockin thermography, in Nondestructive Handbook, Infrared and Thermal Testing, Volume 3, X. Maldague technical ed., P. O. Moore ed., 3 rd edition, Columbus, Ohio, ASNT Press, 2001, 718 p.

[4] Czesław Cempel: Podstawy wibroakustycznej diagnostyki maszyn.

[5] Jerzy Moczko, Lucyna Kramer: Cyfrowe metody przetwarzania sygnałów biomedycznych Wydawnictwo UAM Poznań 2001 S. 89-100.

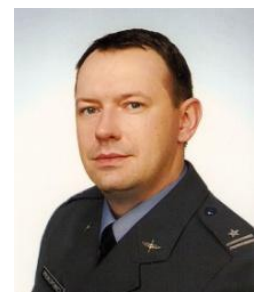

Mjr mgr inz. Wojciech Prokopowicz, a graduate of the Department of Electronics at the Military University of Technology; branch of study "Avionics for aircrafts and helicopters". His main research area during studies was biomedical signals processing. He possess extensive experience in the field of aviation technology in terms of the avionics and airfittings gained during operating Su-22 and F-16 aircrafts. At present, he is the Aviation Safety Inspector in 33rd Air Base in Powidz. He try to apply his knowledge on radar and bio-medical signals processing to nondestructive testing methods; this article is the effect of such trials. 
Detection of cracks in composite materials using hybrid non-destructive testing... Hybrydowa metoda badań nieniszczacych do wykrywania ... 